\title{
Association Between the Polymorphism of the Angiotensin - Converting Enzyme Gene and Breast Cancer Risk Among the Bengalee Caste Hindu Females of West Bengal, India
}

Ghosh Roy $\mathrm{A}^{1^{*}}$, Purkait $\mathrm{P}^{2}$, Raha $\mathrm{O}^{2}$, Das $\mathrm{G}^{3}$, Malay Barman² ${ }^{2}$, Roy $\mathrm{R}^{4}$, B.N Sarkar ${ }^{5}$, A.R Bandopadhyay ${ }^{6}$

Research Article

${ }^{1,2,5,}$ DNA Laboratory, Anthropological Survey of India, Kolkata, India.

3. National Medical College and Hospital, Kolkata,. India.

${ }^{4}$ Cancer Centre Welfare Home and Research Institute, Kolkata, India.

${ }^{6}$ Department of Anthropology, University of Calcutta, Kolkata, India.

\begin{abstract}
Carcinoma of the breast is the most common malignancy among women all over the world. There are a number of risk factors associated with the disease. There is an inter-individual variability in breast cancer risk that attracts that is of anthropological interest. Many studies attempted to find the association between the ace polymorphism (287bp I/D) and prognosis of breast cancer. This study attempted to study the prevalence of ace polymorphism among 108 pathologically confirmed breast cancer patients and 128 controls. The frequency of dd genotype in the malignant samples (57.4\%) was higher than the control group $(25.0 \%$ ), having a significant association with breast cancer risk (or $4.232,95 \%$ ci $=0.083-$ $0.229, \mathrm{p}<0.0001)$. The present findings suggest that the DD genotype may constitute a powerful tool in determining the occurrence and prognosis of breast carcinoma among the Bengalee Hindu caste females from West Bengal.
\end{abstract}

Keywords: ACE gene polymorphism; Breast Cancer; Bengalee Hindu females; West Bengal; India.

\author{
*Corresponding Author: \\ Dr. Abhishikta Ghosh Roy, \\ DNA Laboratory, Anthropological Survey of India, Kolkata, India. \\ E-mail: abhishikta.gr@gmail.com
}

Recieved: December 04, 2014

Accepted: February 21, 2015

Published: February 25, 2015

Citation: Ghosh Roy A et al., (2015) Association Between the Polymorphism of the Angiotensin- Converting Enzyme Gene and Breast Cancer Risk Among the Bengalee Caste Hindu Females of West Bengal, India. Int J Forensic Sci Pathol. 3(2), 85-88. doi: http://dx.doi.org/10.19070/2332287X-1500021

Copyright: Ghosh Roy $\mathbf{A}^{\mathbb{O}} 2015$. This is an open-access article distributed under the terms of the Creative Commons Attribution License, which permits unrestricted use, distribution and reproduction in any medium, provided the original author and source are credited.

\section{Introduction}

Breast cancer is the most prevalent malignancy and the leading cause of death from cancer among women worldwide including India [13]. 1.3 million Women will be diagnosed with breast cancer annually worldwide, and about 465,000 will die from the disease, according to the American Cancer Society (Cancer Facts and Figures, 2010) [1]. Breast cancer shows uneven geographical distribution in occurrence reflecting the influence of local environmental conditions, lifestyle, hormonal / reproductive pattern and genetic predisposition in the development of the disease [11]. Breast cancer being second common cancer in the world, it ranks as fifth cause of death, because of its good prognosis, average in developed countries is $73 \%$ and $57 \%$ in developing countries. The most significant and far the best characterized genetic risk factors of breast cancer development are represented by germ line mutations of the BRCA1 gene [1]. Certain risk factors for breast cancer vary from lifestyle to genetic factors, which accounts for 15 to $25 \%$ of all the cases [17].

The genes involved in breast cancer are expected to be responsible for key processes in cell growth regulation and cell proliferation, including angiogenesis [15]. Recently few studies have attempted to understand the angiogenic and growth factors in angiotensin II which has a wide spectrum of target tissues, including breast epithelial cells $[17,4]$. Angiotensin I gets converted to angiotensin II by the angiotensin-converting-enzyme (ACE). Contradictory results are projected when studies are conducted to assess the role of ACE inhibitors in breast cancer. It is hypothesized that women carrying the low activity alleles of the ACE gene and I/D polymorphisms would have lower ACE levels and decreased synthesis of angiotensin II, and consequently, would be less susceptible to developing breast cancer [5]. ACE inhibitors have been shown to block the process of angiogenesis and tumor growth both in vivo and in vitro though findings on the protective effect of ACE inhibitors on cancer still remain inconsistent $[2,16]$. The ACE gene polymorphism was first identified in 1990 by Rigat and Coworkers. The gene is located in chromosome $17 \mathrm{q} 23$, it is $21 \mathrm{~kb}$ long having 26 exons and has many polymorphisms. The most commonly studied is a $287 \mathrm{bp}$ Alu insertion / deletion (I/D) polymorphism in intron 16 that accounts for $50 \%$ of the variability in circulating ACE levels $[15,7]$.

The present study was attempted to understand the relationship 
of the I/D polymorphism in the ACE gene to breast cancer risk in a case-control study among the Bengalee Hindu caste females of West Bengal, India, which is the first report from West Bengal to the best of our knowledge.

\section{Materials and Methods}

\section{Collection of Samples}

The subjects included in this study are 108 patients with histo pathologically confirmed Breast Carcinoma visiting the Cancer Centre Welfare Home and Research Institute, Kolkata, India, from April, 2010 to December, 2011. Clinical data and detailed family history of each patient were collected with the help of collaborating clinicians after clinical examinations. Ethical approval of the research project using human subjects was obtained from the Institutional Ethical Committee of Anthropological Survey of India, Ministry of Culture, Government of India. Patient samples were mainly collected from The Cancer Centre Welfare Home and Research Institute, Kolkata and National medical College and Hospital, which are the main referral centers for cases related to Breast Carcinoma. Another 127 controls were collected; they were age sex and ethnic group matched without any family history of breast cancer. The demographic data (name, age, caste, address, origin, occupation, family history, educational status, etc) were collected using pre-tested schedules.

\section{DNA Isolation}

Approximately $5 \mathrm{~mL}$ peripheral blood samples were collected in BD Vacutainer K2 EDTA $(6 \mathrm{~mL})$ with written and informed consent from patients with Breast Carcinoma, and from normal individuals as controls, without any history of breast carcinoma. Genomic DNA was prepared from fresh whole blood by using the conventional phenol-chloroform method [12]. Genomic DNA was dissolved in TE $(10 \mathrm{mM}$ Tris- $\mathrm{HCl}$ and $0.1 \mathrm{mM}$ EDTA, $\mathrm{pH}$ 8.0).

\section{PCR Amplification}

Polymerase chain reaction (PCR) was carried out to identify the insertion - deletion polymorphism of $287 \mathrm{bp}$ in intron 16 of ACE gene using designed primers (Table 1) in a reaction of $10.0 \mu \mathrm{L}$ containing 40-100 ng genomic DNA, $0.4 \mathrm{mM}$ of each primer, $0.2 \mathrm{mM}$ of each dNTP, $0.5-1.5 \mathrm{mM}$ of $\mathrm{MgCl}_{2}$ (as appropriate), and 0.2 unit of Taq polymerase (Invitrogen, Carlsbad, CA) in a Thermocycler (GeneAmp-9700; PE Applied Biosystems, Foster City, CA). Annealing temperature is calculated based on Tm of the primer pairs. PCR amplified DNA fragments were analyzed on $2.5 \%$ agarose gel and then visualized by ethidium bromide staining and Documented in Gel Documentation. (190bp fragment in the presence of DD genotype, 490bp for the presence of II genotype, 190bp and 490bp both for ID genotype) (Figure 1).

Appropriate statistical techniques have been applied for analyzing the data using the statistical software SPSS 17.0 version.

\section{Results}

A total of 108 breast cancer patients with histopathologically confirmed carcinoma of the breast and 128 controls without any family history of breast cancer were included in the present study. The age of the breast cancer patients ranged from 30 to 72 years with a mean age 54.04 (SD 10.38) years, and mean age of the controls were 54.10 (SD 8.65), ranging between 32 to 72 years.

Socio demographic characteristics of the participants has been presented in Table 2. The present study revealed no significant differences in age, caste and educational status between cases and controls. But occupation $(p=0.0001)$ and family history $(p=0.0001)$ demonstrated significantly in single women $(11.1 \%)$ and as well married women $(88.9 \%)$ among the breast cancer patients in comparison to controls.

The frequency of ACE genotype with respect to breast cancer patients and controls are shown in Table 2 and figure 2.

Table 3 shows the distribution of ACE genotypes among the studied cohort. $57.4 \%$ of the patients are of DD genotype whereas only $25 \%$ of the controls are found to be of DD genotype. Only $16.7 \%$ of the patients are of II genotype compared to $35.9 \%$ of the controls. The difference in genotypes among the paients and controls are found to be statistically significant $(p<0.0001)$. Result shows hat breast cancer patients are 4.232 times likely to have DD

Table 1. Primer Sequence of ACE gene.

\begin{tabular}{|c|l|l|}
\hline \multicolumn{1}{|c|}{ Primer Sequence } & Product Size & $\operatorname{Tm}\left({ }^{0} \mathrm{C}\right)$ \\
\hline F: 5' - CTGGAGACCACTCCCATCCT'TTCT-3' & 490bp for II & 58 \\
\cline { 1 - 2 } R: 5'-GATGTGGCCATCACATTCGTCAGAT-3' & 190bp for DD & \\
\hline
\end{tabular}

Figure 1. Representative gel documentation of ACE gene polymorphism.

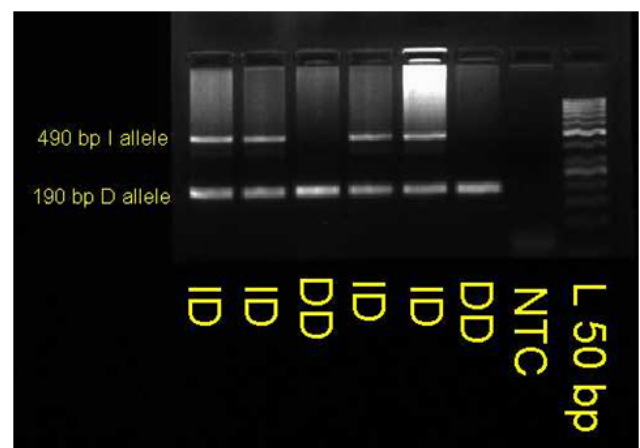

Observed frequencies of genotypes in cancer patients were compared to controls using standard statistical tools. 
Table 2. Socio-demographic characteristics of the subjects.

\begin{tabular}{|c|c|c|c|c|c|}
\hline \multirow{2}{*}{ Socio demographic characteristics } & \multicolumn{2}{|c|}{ Cases } & \multicolumn{2}{|c|}{ Controls } & \multirow{2}{*}{ pValue } \\
\hline & No. & $\%$ & No. & $\%$ & \\
\hline \multicolumn{5}{|l|}{ Marital Status } & \multirow{3}{*}{$\mathrm{p}=0.0015$} \\
\hline Married & 96 & 88.9 & 127 & 100 & \\
\hline Unmarried & 12 & 11.1 & 0 & 0 & \\
\hline \multicolumn{5}{|l|}{ Occupation } & \multirow[t]{4}{*}{$\mathrm{p}=0.0001$} \\
\hline Home maker & 103 & 95.4 & 61 & 47.7 & \\
\hline service & 2 & 1.9 & 32 & 25 & \\
\hline others & 3 & 2.8 & 35 & 27.6 & \\
\hline \multicolumn{5}{|l|}{ Caste } & \multirow{6}{*}{$\mathrm{p}=0.5058$} \\
\hline Brahmin & 23 & 21.3 & 30 & 23.4 & \\
\hline Kayastha & 60 & 55.6 & 67 & 52.3 & \\
\hline Baidya & 15 & 13.9 & 23 & 18 & \\
\hline Baishya & 8 & 7.4 & 4 & 3.1 & \\
\hline SC & 2 & 1.9 & 4 & 3.1 & \\
\hline \multicolumn{5}{|l|}{ Educational Level } & \multirow{6}{*}{$\mathrm{p}=0.7902$} \\
\hline Non-literate & 3 & 2.8 & 4 & 3.1 & \\
\hline Primary level & 11 & 10.2 & 9 & 7 & \\
\hline Secondary & 26 & 24.1 & 34 & 26.6 & \\
\hline Higher Secondary & 26 & 24.1 & 37 & 28.9 & \\
\hline Diploma/Degree & 42 & 38.9 & 44 & 34.4 & \\
\hline \multicolumn{5}{|l|}{ Family History } & \multirow{3}{*}{$p=0.0001$} \\
\hline Yes & 72 & 66.7 & 0 & 0 & \\
\hline No & 36 & 33.3 & 128 & 100 & \\
\hline
\end{tabular}

Figure 2. Frequency of genotypes in cases and controls.

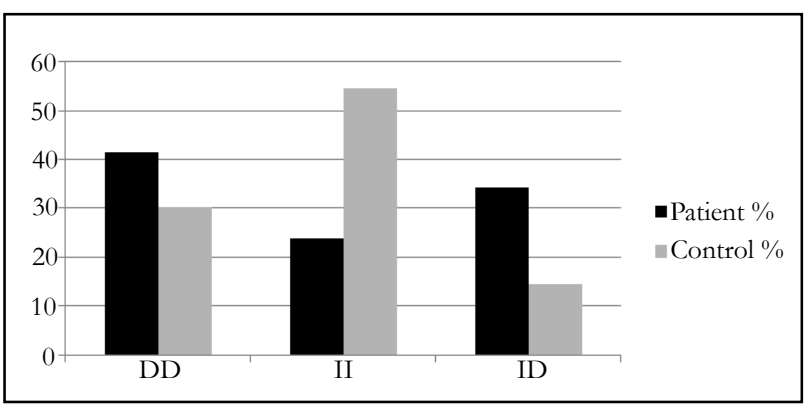

genotype (95\% CI, $0.083-0.229, \mathrm{p}<0.0001)$.

Binary logistic analysis was performed to study the significant predictor variables associated with ACE genotypes. The DD genotype was found to be significantly associated with family history (positive), Number of issues (only one) and use of contraceptive pills (continuously for more than 6months) among the breast cancer patients. Having a family history of breast cancer have 4.1999 times risk of having DD genotype, a women having only one issue are 3.641 times more likely to have DD genotype, whereas when contraceptive pills are administered continuously for more than 6months it is likely that a women will have 2.370 times more risk of having DD genotypes.

\section{Discussion}

To the best of our knowledge, this is the first study that examines the relationship between the ACE gene polymorphisms and breast cancer risk among the Bengalee Hindu females of West
Bengal. Breast cancer is one of the most common malignancies in women. It continues to be a major burden and cause of death among women worldwide. Molecular biology is a promising field that may contribute considerably to diagnosis of breast cancer and its metastasis, addressing major problems with early detection, accurate staging, and monitoring of breast cancer patients. The development of human breast cancer is a multi-step process, arising from genetic alterations that drive the transformation of normal mammary epithelial cells into highly malignant derivatives [14].

The present study demonstrates high frequency of DD genotypes, which might be associated with breast cancer risk. A recent study has reported that the DD genotype might be an adjunct with poor prognostic factors and influence tumor course [18]. Angiotensin is a potent angiogenic factor reported to participate in the development and promotion of the tumorigenesis $[3,6]$.

Our results are consistent with the findings of an earlier study [6]. 
Table 3. Genotype Frequencies of ACE gene in cases and controls.

\begin{tabular}{|c|c|c|c|c|c|c|}
\hline \multirow{2}{*}{ ACE } & \multicolumn{2}{|c|}{ Patient } & \multicolumn{2}{c|}{ Control } & \multirow{2}{*}{$\boldsymbol{\varkappa}^{\mathbf{2}}$} & OR \\
\cline { 2 - 5 } & $\mathbf{N o .}$ & $\mathbf{\%}$ & $\mathbf{N o .}$ & $\mathbf{\%}$ & \multirow{2}{*}{$<0.0001$} & $\begin{array}{c}4.232 \\
(0.083-0.229) \\
\mathrm{P}<0.0001\end{array}$ \\
\hline DD & 62 & 57.4 & 32 & 25 & & \\
\hline ID & 28 & 25.9 & 50 & 39.06 & & \\
\hline II & 18 & 16.7 & 46 & 35.9 & & \\
\hline Total & 108 & 100 & 128 & 100 & & \\
\hline
\end{tabular}

Table 4. Binary logistic regression analysis of Risk Factors for breast cancer patients with DD.

\begin{tabular}{|c|c|c|c|}
\hline Risk Factors & ODDS Ratio & $\mathbf{9 5 \%}$ CI & p Value \\
\hline Family History (positive) & 4.200 & $0.189-0.524$ & 0.000 \\
\hline Number of Issues (One) & 3.641 & $0.092-0.308$ & 0.000 \\
\hline Oral Contraceptive Use (more than 6 months) & 2.37 & $0.037-0.403$ & 0.019 \\
\hline
\end{tabular}

The I/D in the ACE gene might not play a direct role in regulating the ACE transcription; instead it is in linkage disequilibrium with the regulatory elements of ACE gene.

We found a significant association of the DD genotype in cases with positive family history, number of issues and oral contraceptive use $(\mathrm{p}<0.001)$.

In summary, our results suggest that ACE gene polymorphism is associated with breast cancer predisposition and development, though there are certain other genetic and lifestyle factors that modify the risk of breast cancer. Our results support the evidence that ACE is etiologically linked to breast cancer development and progression. The ID and II genotype may confer a protective effect against breast cancer, and therefore ACE (I/D) polymorphism might be used as a genetic marker for breast cancer risk among the Bengalee Hindu Caste Female Breast Cancer Patients of West Bengal.

\section{Acknowledgement}

This research work is supported by the grant from Anthropological Survey of India, Ministry of Culture, Government of India. I am thankful to the patients with Breast Carcinoma and control subjects for voluntarily taking part in this research work and donating their blood samples.

\section{References}

[1]. American Cancer Society (2010). Cancer Facts and Figures. Breast Cancer.

[2]. Fujita M, Hayashi I, Yamashina S (2002) Blockade of angiotensin At1a receptor signaling reduces tumor growth, angiogenesis, and metastasis. Biochem Biophys Res Commun. 294:441-7.

[3]. Fernandez LA, Twickler J, Mead A (1985) Neovascularization produced by angiotensin II. J Lab Clin Med. 105:141-5.

[4]. Greco S, Muscella A, Elia MG (2002) Activation of angiotensin II type I receptor promotes protein kinase $\mathrm{C}$ translocation and cell proliferation in human cultured breast epithelial cells. J Endocrinol. 174:205-14.

[5]. Koh WP, Yuan Jm, Sun CL (2003) Angiotensin I-converting enzyme(ACE) gene polymorphism and breast cancer risk among chinese women in Singapore. Cancer Res. 63:573-8.

[6]. Le Noble FA, Hekking JW, Van Straaten HW, Slaaf DW, Struyker Bouldier HA (1991) Angiotensin II stimulates angiogenesis in the chorio - allantoic membrane of the chick embryo. Eur J Pharmacol. 195:305-6.

[7]. McKenzie CA, Abecasis GR, Keavney B (2001) Trans-ethnic fine mapping of a quantitative trait locus for circulating angiotensin I-converting enzyme (ACE). Hum Mol Genet. 10:1077-84.

[8]. Mitrunen K, Hirvonen A (2003) molecular epidemiology of sporadic breast cancer. The role of polymorphic genes involved in oestrogen biosynthesis and metabolism. Mutat Res. 544:9-41.

[9]. Miki Y, Swensen J, Shattuck-Eidens D, Futreal PA, Harshman K, et al. (1994) A strong candidate for the breast and ovarian cancer susceptibility gene BRCA1. Science 266:66-71

[10]. Miki Y, Swensen J, Shattuck-Eidens D, Futreal PA, Harshman K, et al. (1994) A strong candidate for the breast and ovarian cancer susceptibility gene BRCA1. Science 266 (5182): 66-71.

[11]. Parkin DM, Bray F, ferlay J, Pisani P (2001) Estimating the world cancer burden: GLOBOCAN. Int. J. Cancer 94: 153-156.

[12]. Sambrook J, Russel DW (2001) Molecular cloning: a laboratory manual. In: Irwin N (ed) Science. Cold Spring Harbor Press, Cold Sprig Harbor, NY.

[13]. Samson M, Swaminathan R, Rama R, Sridevi V, Nancy KN, et al .(2007) Role of GSTM1 (Null/Present), GSTP1 (Ile105Val) and P53 (Arg72Pro) Genetic Polymorphisms and the Risk of Breast Cancer - A Case Control Study from South India. 8:253-257.

[14]. Syeed Nidda, Abdullah S, Sameer A.S, Akhtar S, Husain, et al. (2012) ACE gene polymorphism in breast cancer paients of ethnic Kashmiri population. Chronicles of Young Scientists. 1(4): 40-45.

[15]. Tiret L, Rigat B, Visvikis S (1992) Evidence from combined segregation and linkage analysis, that a variant of the angiotensin I-converting enzyme (ACE) gene controls plasma ACE levels. Am J Hum Genet.51:197-205.

[16]. Volpret OV, Ward WF, Lingen MW (1996) Captopril inhibits angiogenesis and slows the growth of experimental tumors in rats. J Clin Invest. 98: 6719.

[17]. Walther T, Menrad A, orzechowski HD (2003) Differential regulation of in vivo angiogenesis by angiotensin II receptors. FASEB J. 17: 2061-7.

[18]. Yaren A (2007) Insertion/Deletion polymorphism of the angiotensin I-converting enzyme gene in patients with breast cancer and effects on prognostic factors. J Investig Med. 55:255-61. 